\title{
Influence of age on the spermiogramic parameters of native sheep
}

\author{
M. R. Hassan, S. Pervage, M. Ershaduzzaman and M. A. I. Talukder \\ Goat \& Sheep Production Research Division, BLRI, Savar, Dhaka-1341, Bangladesh
}

\begin{abstract}
The study was conducted to evaluate the qualities of ram semen in different age groups (one to four years) were evaluated. The parameters included testes length $(\mathrm{cm})$, testes breadth $(\mathrm{cm})$, scrotal circumference $(\mathrm{cm})$, live weight $(\mathrm{kg})$, semen volume $(\mathrm{ml}), \mathrm{P}^{\mathrm{H}}$, sperm concentration $\left(\times 10^{9}\right)$, motility $(\%)$, percentage of live, dead and normal, abnormal spermatozoa of native sheep. The average semen volume $(\mathrm{ml})$ found to be $0.60,0.91,0.85$ and 0.87 ; sperm concentration $(10 \% \mathrm{ml}) 1.03,3.27,4.45$ and 4.17 and finally motility (\%) were found to be $68.07,75.03,75.01$ and 76.25 respectively for the $1^{\text {st }}, 2^{\text {nd }}, 3^{\text {rd }}$ and $4^{\text {th }}$ year age of native ram. The effects of age on all parameters (testes length, semen volume, semen $\mathrm{p}^{\mathrm{H}}$, sperm concentration, motility, viability, normal spermatozoa) were significant except testes breadth and scrotal circumference. The value of all of these parameters increased linearly up to three years with the increase of age except $\mathrm{P}^{\mathrm{H}}$. The result of the present study indicated that scrotal diameter, serving capacity; normal and live spermatozoa were comparatively better during the $3^{\text {rd }}$ year than the $1^{\text {st }}$ and $2^{\text {nd }}$ year of age while the values were almost similar at $3^{\text {rd }}$ and $4^{\text {th }}$ year of age. With the increasing of age, the semen quality improved and stabilized up to at the age of 3 years.
\end{abstract}

Keywords: Native sheep, Spermiogramic parameter, Age

\section{Introduction}

Sheep is one of the most important animals among the livestock species. During the last twelve years sheep population increased 2.53 times, with annual growth rate of 5\% (BBS, 2008). These animals are mostly raised by landless, marginal farmers and the baperies in Char areas. This growth rate may be increased many times by providing adequate care and sound breeding knowledge. Artificial Insemination in sheep is a well known technique all over the world. Small ruminants show various patterns in reproductive activity that is shaped by age and seasonal changes in their habitats. Selection for fertility in sheep can be accomplished through selecting for correlated traits in young rams such as age, testes size, testes length etc. (Land and Carr, 1975). After observing testis growth consistent differences in the development of sexual activity and of sperm production were found by Louda et al. (1981) who suggested that young rams of prolific breeds (Romanov and Finnish Landrace) might differ in their potential reproductive performance. In general, sexual development of ram lamb appears to be more closely associated with body growth than with chronological age (Dyrmundsson and Lees, 1972). David et al. (2007) found that in Lacaune and Manech tete rousse sheep motility, concentration and number of spermatozoa were higher up to the age between 2-3 years then declined chronologically. Proper Artificial Insemination would be conducted with better knowledge of ram's age, testes size, semen characteristics which would improve reproductive efficiency and enhance breeding schemes and the rate of genetic gain. The purpose of this investigation was to know the changes of testicular characteristics and spermiogramic parameters influencing them on age variation and their correlation with semen production.

\section{Materials and Methods}

Thirty-six indigenous rams of average body weight $23 \pm 2.45$ were selected from Bangladesh Livestock Research Institute. On the basis of age the animals were divided into four groups (1year, 2year, 3year and 4year of age) having nine rams in each. Rams were kept separately in slatted floor permanent house and allowed to graze 6-7 hours/day along with supplemented concentrate (300 gm/ram/day) and germinated gram (10 gm/ram/day). Water was provided ad libitum. The scrotal circumference (SC), testis length (TL), testis breath (TB) was recorded fortnightly by spermatic cord grasping in the first week until the end of the experiment in centimeter and body weight $(\mathrm{kg})$ were recorded fortnightly. The rams were trained up for semen collection into an artificial vagina (AV) using receptive restrained ewes. Semen of four groups of ram was collected weekly using AV. Immediately after collection, semen samples were placed in a water bath at $37.5^{\circ} \mathrm{C}$ and semen volume was estimated in a calibrated semen collection tube and $\mathrm{pH}$ was determined by using $\mathrm{pH}$ meter. Transparency and consistency of semen was determined with eye estimation. Motility was determined on a warm stage $\left(35^{\circ} \mathrm{C}\right)$ under a light microscope. 
Sperm concentration was determined by means of a Neubauer haemocytometer under a 40x magnification. Percentages of live and dead sperm and; normal and abnormal sperm were determined by eosine-aniline and eosine-negrosin staining on a glass slide respectively (Vilakazi and Webb, 2004). Data were analyzed using SPSS (Statistical Packages for Social Science version 11.5) and correlation was measured by Pearson's correlation test.

\section{Results and Discussion}

The least square means and standard error of body weight (BW), semen volume (SV) and sperm concentration (SPC) of different age groups were highly significant $(p<0.001)$. Although the TL of rams in different age groups were significant $(p<0.01)$ but the effect of age on breadth and SC were nonsignificant $(p>0.05)$ (Table 1$)$. Scrotal diameter increased rapidly during the $2^{\text {nd }}$ year of age and grew slowly over the $3^{\text {rd }}$ year (Mandiki et al 1997). Testis diameter generally increased until about 34 weeks of age and showed seasonal variations thereafter in Suffolk lambs recorded by Moore and Sanford (1985). In other research, Barwick et al. (1985) determined that the mean testis diameter in Border Leicester inactive rams was smaller than in active rams. The trend of testicular and scrotal development observed in this study was similar to that described by Ghannam et al. (1977) in Awassi lambs, Schoeman and Combrink (1987) in Dorper, Dohne Merino and Meat Master Lambs who obtained that the testes length increased rapidly up to 2 years and the age of the ram also significantly $(p<0.01)$ affected by $\mathrm{pH}$. With increase in age, ram showed increase percentages of motility and viability of sperm at one, two, three and four years old rams. Mandiki et al (1997) reported that sperm motility increases and abnormal sperm decreases with the increasing of age. In another research sires influenced the testis diameter of the progeny, and effects of sires showed age and seasonal variations. Sires also influenced the percentage of abnormal spermatozoa, but the effect was lower than that on the testis diameter (Colas et al., 1990).

From this experiment, semen was examined for transparency and consistency, which varied from an appearance of cloudy to opaque and watery to thick creamy. In younger stage (one year) the semen consistency was watery to thin creamy and changed gradually (thick creamy) with the increasing age up to three years and then normal sperm percentage of one year aged ram was lower while higher results were obtained in the other three groups.

Table 1. Spermiogramic parameters in native sheep of Bangladesh

\begin{tabular}{|l|c|c|c|c|c|}
\hline \multirow{2}{*}{ Parameters } & \multicolumn{5}{c|}{ Ages } \\
\cline { 2 - 6 } & 1 year & 2 year & 3 year & 4 year & Probability \\
\hline Body weight $(\mathrm{kg})$ & $21.58^{\mathrm{a}} \pm 2.44$ & $25.62^{\mathrm{b}} \pm 3.16$ & $27.94^{\mathrm{c}} \pm 1.61$ & $29.01^{\mathrm{c}} \pm 5.18$ & $\mathrm{p}<0.001$ \\
\hline Testes length $(\mathrm{cm})$ & $10.73^{\mathrm{a}} \pm 1.01$ & $11.78^{\mathrm{b}} \pm 1.05$ & $12.60^{\mathrm{c}} \pm 1.67$ & $12.08^{\mathrm{c}} \pm 1.06$ & $\mathrm{p}<0.01$ \\
\hline Testes breadth $(\mathrm{cm})$ & $5.31 \pm 0.29$ & $4.98 \pm 0.81$ & $5.00 \pm 0.71$ & $5.21 \pm 0.59$ & $\mathrm{NS}$ \\
\hline Scrotal circumference (cm) & $21.78 \pm 1.73$ & $22.10 \pm 1.85$ & $22.50 \pm 1.22$ & $22.41 \pm 2.02$ & $\mathrm{NS}$ \\
\hline Semen volume (ml) & $0.60^{\mathrm{a}} \pm 0.12$ & $0.91^{\mathrm{b}} \pm 0.16$ & $0.85^{\mathrm{b}} \pm 0.11$ & $0.87^{\mathrm{b}} \pm 0.16$ & $\mathrm{p}<0.001$ \\
\hline Semen pH & $7.71^{\mathrm{a}} \pm 0.44$ & $7.08^{\mathrm{b}} \pm 0.70$ & $6.94^{\mathrm{b}} \pm 0.47$ & $7.10^{\mathrm{b}} \pm 0.44$ & $\mathrm{p}<0.01$ \\
\hline Sperm concentration $\left(10^{9} / \mathrm{ml}\right)$ & $1.03^{\mathrm{a}} \pm 0.61$ & $3.27^{\mathrm{c}} \pm 0.34$ & $4.45^{\mathrm{c}} \pm 0.39$ & $4.17^{\mathrm{c}} \pm 0.58$ & $\mathrm{p}<0.001$ \\
\hline Motility $(\%)$ & $68.07^{\mathrm{a}} \pm 2.14$ & $75.03^{\mathrm{b}} \pm 2.13$ & $75.01^{\mathrm{b}} \pm 1.36$ & $76.25^{\mathrm{b}} \pm 2.15$ & $\mathrm{p}<0.01$ \\
\hline Viability $(\%)$ & $85.80^{\mathrm{a}} \pm 3.24$ & $89.81^{\mathrm{b}} \pm 4.12$ & $90.29^{\mathrm{b}} \pm 2.16$ & $91.65^{\mathrm{b}} \pm 3.56$ & $\mathrm{p}<0.01$ \\
\hline Normal sperm $(\%)$ & $89.20^{\mathrm{a}} \pm 3.16$ & $91.61^{\mathrm{b}} \pm 2.18$ & $94.32^{\mathrm{c}} \pm 3.54$ & $94.63^{\mathrm{c}} \pm 1.69$ & $\mathrm{p}<0.001$ \\
\hline
\end{tabular}

${ }^{a b c}$ means within different superscripts in the same row differ significantly $(p<0.01)$, NS= Non-significant

\section{Correlation among spermiogramic parameters}

The correlation of testis length with testis breadth, scrotal circumference, body weight, sperm volume and sperm concentration as well as sperm motility were positive $(p<0.01)$ except $\mathrm{pH}$. However, body weight and age closely correlated with testis measurements. Similarly, Salhab et al. (2001) reported significant correlations between body weight and testis parameters. Testis length could provide a useful estimate of testicular growth since its correlations with the other testicular measurements were the highest (Land and Carr, 1975). These results were in agreement with the findings of Kumi-Diaha et al. (1985) and Foster et al. (1989). Positive correlation was found between semen volume and sperm concentration. Although testis length and scrotal circumference was positively correlated with the sperm concentration but the negative result was obtained in case of testis breadth. 
Table 2. Correlation coefficients ( $r$ ) among spermiogramic parameters of native sheep with different age groups

\begin{tabular}{|l|c|c|c|c|c|c|c|}
\hline Parameters & TL & TB & SC & BW & SV & pH & SPC \\
\hline TB & 0.287 & & & & & & \\
\hline SC & $0.396^{\star}$ & $0.599^{\star \star}$ & & & & & \\
\hline BW & $0.479^{\star}$ & 0.212 & $0.504^{\star \star}$ & & & & \\
\hline SV & $0.611^{\star *}$ & 0.102 & 0.229 & $0.568^{\star \star}$ & & & \\
\hline pH. & $-0.516^{\star *}$ & -0.102 & -0.123 & -0.247 & $-0.381^{\star}$ & & \\
\hline SPC & $0.589^{\star \star}$ & -0.128 & 0.108 & $0.664^{\star \star}$ & $0.634^{\star \star}$ & $-0.444^{\star \star}$ & \\
\hline Motility & $0.414^{\star}$ & 0.009 & 0.017 & $0.494^{\star \star}$ & $0.550^{\star *}$ & $-0.497^{\star *}$ & $0.655^{\star *}$ \\
\hline
\end{tabular}

* Correlation is significant at 0.05 levels, ** Correlation is significant at 0.01 levels

Other researchers (Vilakazi and Webb, 2004) reported a strong correlation between body weight and scrotal circumference. Even more encouraging in the present study are the favorable phenotypic correlations of semen and sperm characteristics with testicular measurements.

\section{Conclusion}

In conclusion, scrotal diameter, serving capacity and; normal and viable spermatozoa were optimum during the $3^{\text {rd }}$ year than the $1^{\text {st }}$ and $2^{\text {nd }}$ year of age. As age increased, semen quality improved and stabilized at the age of $3^{\text {rd }}$ to $4^{\text {th }}$ years. The results of this study, lead to postulate that the suitability of testicular and scrotal measurements as a criteria for early selection of ram lamb. Further studies on spermatogenetic activity will be needed to confirm the present results.

\section{Acknowledgements}

We acknowledge the financial support of GOB funded national project entitle "Conservation and improvement of native sheep through community farming and commercial farming", Bangladesh Livestock Research Institute (BLRI).

\section{References}

Barwick, S.A., Kilgour, R.J. and Gleeson, A.C. 1985. Ram mating performance in Border Leicester and related breed types. I. Pen teat performance and measures of testis diameter. Aust. J. Exp. Agr., 25, 9-16.

BBS, 2008. Bangladesh Census of Agriculture, 2007-2008. Bangladesh Bureau of Statistics, Dhaka.

Colas, G; Lefebre, J. and Guerin, Y. 1990. A study of the transmission from sire to male progeny of seasonal variations in testis diameter and percentage of abnor-mal spermatozoa in lle-de-France ram. Reprod. Nutr. Develop., 30, 589-603.

David, I; Bodin, L; Lagriffoul, G; Manfredi, E. and Robert-Granie, C. 2007. Character process model for semen volume in Al rams: evaluation of correlation structures for long and short term environmental effects. Genet. Sel. Evol. 39(2007) 55-57.

Dyrmundsson, O.R. and Lees, J.L. 1972. Puberty development of Clun Forest ram lambs in relation to time of birth. J. Agr. Sci. (Camb), 79, 83-89.

Flowers, W.L. 1997. Management of sheep for efficient semen production. J. Reprod. Fert. Suppl.52: 67-78.

Foster, R.A., Ladds, P.W; Homann, D. and Briggs, G.D.1989. Therelationship of scrotal circumference to testicular weight in rams. Aust. Vet. J., 66, 20-22.

Ghannam, S.A.M., Medhat, M.N and El-Tawil, A. 1977: Puberty in Awassi ram lambs. II. Development of the testes, epididymis and seminal vesicles. Z. Tierzuchtg. Zuchtgsbiol., 94, 235-541.

Kumi-Diaka, J.A., Adesiyum, A.A; Sekoni, V. and Ezeokoli, C.D. 1985: Scrotal dimensions and ejaculate charac-teristics of three breeds of sheep in Tropical Nigeria. Theriogenology, 23, 671-677.

Land, R.B. and Carr W.R. 1975. Testes growth and plasma LH concentration following hemicastration and its relation with female prolificacy in sheep. J. Rep. Fertility, 45, 495. 
Lauda, F., Donery, J.M., Stolc, L, Krizek, J. and Smerda, J. 1981. The development of sexual activity and semen production in ram lambs of two prolific breeds, Romanov and Finnish Landrace. Anim. Prod., 33, 143-148.

Mandiki, G.S.N; Derycke, M., Bister, J.L. and Paquay, R. 1997. Influence of season and age on sexual maturation parameters of Texel, Suffolk and Ile-de-France rams 1. Testicular size, semen quality and reproductive capacity. Laboratoire de Physiologie Animale, Facultés Universitaires Notre-Dame de la Paix, Rue de Bruxelles 61, 5000 Namur, Belgium.

Moore, C. and Sanford, L.M. 1985. Genetic in.uenceofpre-dictability of testis function of rams. Research Reports Department of Animal Science, McGill University, pp 71-78.

Salhab, S.A; Zarkawi, M; Wardeh, M.F; Al-Masri, M.R. and Kassem R. 2001. Development of testicular dimen-sions and size, and their relationship to age, body weight and parental size in growing Awassi ram lambs. Small Rum. Resch., 40, $187-191$.

Schoeman, S.J; Els, H.C. and Combrink, G.C. 1987. A preliminary investigation into the use of testis size in crossbred rams as a selection index for ovulation rate in female relatives. S. Afr. J. Anim. Sci., 17, 144-147.

Vilakazi, D.M. and Webb, E.C. 2004. Effect of age and season on sperm morphology of ram at an artificial insemination centre in South Africa. S. Afr. J. Anim. Sci. 34, 62-69. 